\title{
Milk yield and composition in cows fed rations with different energy and protein sources
}

\author{
J. Strzetelski' ${ }^{1}$, K. Krawczyk ${ }^{1}$, J. Kowalczyk ${ }^{3}$, S. Osięglowski ${ }^{2}$ \\ and H. Pustkowiak ${ }^{4}$
}

\author{
${ }^{\prime}$ Department of Animal Nutrition, \\ 'Experimental Station. \\ Research Institute of Animal Production \\ 32.083 Balice, Poland \\ ${ }^{3}$ The Kielanowski Institute of Animal Physiology and Nutrition, \\ Polish Academy of Sciences \\ 05-110 Jablonna, Poland \\ 'Cracow Agricultural University, Department of Animal Husbandry \\ Al. Mickiewicza 24/28, 30-059 Kraków, Poland
}

(Received 19 February 2001; accepted 6 November 2001)

\begin{abstract}
The experiment was carried out on 151 Black-and-White cows from calving to 100 days of lactation. The animals were assigned to 8 groups by the analogue method. The influence of feeding diets containing different proteins from keratin meal (low rumen degradability) or lupin (high rumen degradability) and different energy sources such as slowly fermentable maize starch, easily fermentable barley meal or oil from rape seeds on the interaction of these factors in milk yield and composition, and feed conversion was studied. The cows were fed rations formulated according to INRA standards (IZ-1NRA, 1997).

The cows were milked twice daily and daily milk outputs were recorded. Milk samples were drawn once a week to determine fat, protein and tactose contents. Additional samples were taken at 35,84 and 100 days of lactation to determine the urea content; fatty acids were determined in samples taken on day 100 of lactation. The body weight of cows was determined on day 21 prior to calving and at $2,10,35,84$ and 100 days after calving.

The results of the experiment showed that despite the rations being balanced for energy and protein, the type of dietary protein (different rumen degradability coefficients) can affect the yield of milk and its components in high-yiclding cows. The extent of starch degradation in the rumen appeared to be of limited influence on these parameters. The highest milk protein content was obtained with the lupin-barley combination (a significant protein by starch interaction) indicating that adequate synchronization of energy and protein for bacterial yield in the rumen may affect the level of protein in milk. Increased intake of rape seeds oil had a favourable effect on milk and lactose yield
\end{abstract}


without a significant effect on milk composition. The effect of rape seeds on milk performance was not related to the other feed components in terms of the rate of protein and carbohydrate degradation, as the protein $\mathrm{x}$ starch $\mathrm{x}$ oil interaction was not significant. The source of protein, starch and oil from rape seeds had only a slight effect on changes in the fatty acid composition of milk fat.

KEY WORDS: cow, cnergy sources, protein sources, milk yield, milk composition

\section{INTRODUCTION}

In recent years, the efficiency of protein with varying rumen degradability and of energy from various feeds in the feeding of high-yielding cows has been intensively studied. However, the results obtained are not unequivocal. Some experiments have shown that rumen undegradable protein increases the intestinal availability of amino acids (Beever, 1993), but when high quality bulky feeds are fed, the reaction of cows to undegradable protein may be different as the advantageous influence of such protein is manifested only when the supply of protein or amino acids to the small intestine is not sufficient (Ulyatt, 1997; Hongerhold and Muller, 1998). Furthermore, increasing rumen undegradable protein in the diet may cause a deficit of degradable protein in the rumen and limit the supply of microbial protein to the small intestine for digestion (Hoover and Stokes, 1991; Dijkstra et al., 1998). A similar situation can be found when feeding starch with different susceptibility to rumen fermentation. Easily fermentable starch delivers energy for microbial synthesis in the rumen but decreases the amount of starch for digestion in the intestine.

The applied systems of ruminant feeding aim to synchronize the rate of protein digestion and carbohydrate fermentation (Castillo et al., 2000), however such synchronization does not always improve milk yield and composition (Henderson et al., 1998; Kolver et al., 1998).

The aim of the present study was to investigate if feeding high yiclding cows diets with protein and energy balanced according to standards of ruminant nutrition (IZ-INRA, 1997) and containing a combination of various sources of starch with protein of different rumen degradability as well as supplementing the diet with rape seeds oil would influence milk production and composition.

\section{MATERIAL AND METHODS}

\section{Animals and feeding}

The experiment was carried out on 151 Black-and-White Lowland cows selected 3 weeks before expected calving from a herd of 500 cows. The animals were divided into 8 groups of 17-20 cows according to an analogue method based on HF 


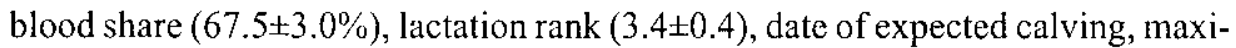
mal milk production at peak of the last lactation, and body weight at 21 days bcfore calving $(735.9 \pm 16.0 \mathrm{~kg})$. The experiment lasted from calving to day $100 \mathrm{of}$ lactation.

Animals were fed concentrates containing, respectively for groups, highly (lupin - L) or poorly (feather keratin meal - K) rumen degradable protein and simultaneously starch that was either easily (barley - B) or slowly (maize - M) fermented in the rumen as a source of energy supplemented with rape seeds $(O)$. The feeding regimen and concentrate components for the respective groups of animals are given in Table 1.

The daily ration for all groups during the experimental period contained changeable, but in a similar way in all groups, proportions of silage, meadow hay (from 1 to $2 \mathrm{~kg}$ ) and $1 \mathrm{~kg}$ dried sugar beet pulp. The main component of the diet fed during the entire time of the experiment was a silage of maize and/or whole barley plants with lucerne in a proportion of $85: 15 \%$ of dry matter, fed no more than $20 \mathrm{~kg}$ daily. Depending on feed availability other silages were also fed: grass with 10 or $30 \%$ lucerne (maximum $15 \mathrm{~kg} /$ day), sugar beet tops ( $12 \mathrm{~kg} /$ day), and a silage of sugar beet pulp $(7 \mathrm{~kg} / \mathrm{day})$. The basal rations were supplemented with soyabean oilmeal (from 0.3 to $1.2 \mathrm{~kg} /$ day) equalizing protein and energy for milk production.

TABLE 1

Feed components of concentrates, $\%$

\begin{tabular}{|c|c|c|c|c|c|c|c|c|}
\hline \multirow{6}{*}{ Feed component } & \multicolumn{8}{|c|}{ Protein source } \\
\hline & \multicolumn{4}{|c|}{ lupin } & \multicolumn{4}{|c|}{ feather kerain meal } \\
\hline & \multicolumn{4}{|c|}{ starch source } & \multicolumn{4}{|c|}{ starch source } \\
\hline & \multicolumn{2}{|c|}{ barley } & \multicolumn{2}{|c|}{ maize } & \multicolumn{2}{|c|}{ barley } & \multicolumn{2}{|c|}{ maizc } \\
\hline & \multicolumn{8}{|c|}{ Groutps $^{2}$ (energy source) } \\
\hline & LB & LBO & LM & $\mathrm{LMO}$ & $\mathrm{KB}$ & $\mathrm{KBO}$ & $\mathrm{KM}$ & $\mathrm{KMO}$ \\
\hline Barley, ground & 61.7 & 54.7 & - & - & 73.7 & 67.4 & - & - \\
\hline Maize, ground & - & - & 62.7 & 58.5 & - & - & 73.7 & 70.6 \\
\hline Soyabcan oilmeal & 12.0 & 12.0 & 12.0 & 12.0 & 12.0 & 11.7 & 12.0 & 11.8 \\
\hline Lupin, ground & 23.0 & 23.0 & 22.0 & 22.0 & - & - & - & - \\
\hline Feather keratin meal & - & - & - & - & 10.0 & 9.7 & 10.0 & 9.8 \\
\hline Rape seeds & - & 7.0 & - & 4.2 & - & 7.0 & - & 3.6 \\
\hline Mineral mixlure & 2.5 & 2.5 & 2.5 & 2.5 & 2.5 & 2.4 & 2.5 & 2.4 \\
\hline Limestone & 0.5 & 0.5 & 0.5 & 0.5 & 1.5 & 1.5 & 1.5 & 1.5 \\
\hline Adhesive & 0.3 & 0.3 & 0.3 & 0.3 & 0.3 & 0.3 & 0.3 & 0.3 \\
\hline
\end{tabular}

1 composition, \%: $\mathrm{CaHPO}_{4}, 32 ; \mathrm{NaHCO}_{3}, 15.8 ; \mathrm{NaCl}, 6$; MgO, 7; Premix B (Pozbac-Poznań), 20; dolomite, 15; wheat bran, 4.2

minerals, in $1 \mathrm{~kg}(\mathrm{~g})$ : P, 90; Ca, 171; Mg, 53; Na, 55; (mg): Cu, 613; Zn, 197; $\mathrm{Mn}, 398 ; \mathrm{Co}, 4.0$; Se, 3,$8 ;$ J, 0.04; (IU): vit. A, 91.; vit. $D_{3}, 7589$; vit. E, 1140

2 L - lupin; B - barley; O - rape seeds as a source of oil; M - maizc; K - keratin meal 
Deficiency of methionine (20-25\%) in the diets was compensated with $16 \mathrm{~g} /$ day of Smartamine $\mathrm{M}^{\mathrm{TH}}$ (Rhône-Poulenc) containing $70 \%$ of methionine protected from rumen degradation. The methionine content in feeds was adopted from the INRA'tion ver. 2.63 program (1996).

The protein and energy value of feeds, proportion of ingredients in concentrates and daily rations for cows were formulated according to IZ-INRA (1997) feeding standards using WINWAR ver. 1.3 and WINMIX ver. 1.3 and INRA'tion ver. 2.63 (1996) software based on our own chemical analysis of feed. The nutritive value of feeds was calculated based on the results of analysis for nutrient contents using coefficients of crudc protein degradability in the rumen and intestinal digestibility of rumen undegraded protein for the majority of feed values given by INRA (1988), except keratin meal, for which values were taken from the experiment of Strzetelski et al. (1999).

Cows were fed individually: silage twice a day, concentrates with dried sugar beet pulp and soyabean oilmeal three times, and meadow hay after afternoon milking. Refusals were collected for analysis. Cows were milked twice a day with individual control of milk production. The body weight of cows was controlled on the day 21 before and days 2,10,35, 84 and 100 after calving.

\section{Sampling and analysis}

Samples of roughages, concentrates and refusals were analysed in two-week intervals for nutrient contents according to AOAC (1990) methods. Silages were analysed for acetic, butyric and lactic acid content using Varian 30400 gas chromatography equipment.

Milk samples taken once per week were analysed for protein, fat and lactose content using a Milkoscan apparatus, samples taken on days 35, 84 and 100 were analysed colorimetrically (Biochemtest, $\mathrm{POCH}$, Poland) after deproteinization with zinc sulphate, potassium ferrocyanide and activated charcoal for urea content. In the samples of milk taken on day 100 of lactation, fatty acids were determined with a GLC Pye Unicam apparatus with flame ionized detector and $30 \mathrm{~m}$ Supel Covex $10 \mathrm{~m}$ column. Esterification of fatty acids was achieved by treatment with sodium methylate according Mann's (1964) procedure.

\section{Calculations}

Milk yield at the peak of the last lactation $\left(\mathrm{PM}_{11}\right)$ was calculated according the equation: $\mathrm{PM}_{11}=\mathrm{P}_{300} / 190$, where $\mathrm{P}_{300}$ is milk yield for 300 days of lactation.

Daily nutrient intake was calculated as a weighted mean taking into account the nutrient content in feeds and intake by individual cows during the experimental period. 
The results were subjected to statistical analysis according the GLM procedure of SAS (1989). Maximal milk production at the peak of lactation and body weight changes in the experimental period were analysed with one-way analysis of variance, other results with three-way analysis of variance. For the examined period of lactation, a fitted curvilinear milk yield on individual days of lactation, based on the multiple regression method, was obtained. The equation used was:

$$
y=A \cdot x^{\alpha} \cdot e^{a x} \text { or in logarithmic form: } \ln y=\ln A+\alpha \ln x+a x
$$

where:

y - daily milk yield

$\alpha \quad$ - coefficient of linear correction between Iny and $\ln x$

$\ln \mathrm{A}$ - displacement

a - coefficient of linear correction for variable $x$, i.e. for lactation day.

\section{RESULTS}

The chemical composition of feeds is given in Table 2, and mean nutrient intake in Table 3 . Feeds given to animals were eaten almost completely, occasionally only small amounts of roughage refusals were found. Intake of PDIN and PDIE with daily feed was higher $(\mathrm{P}<0.01)$ in groups of animals fed rations containing keratin meal than lupin. In the case of PDI and UFL, significant interaction of protein $\mathrm{x}$ starch was found, at the same time PDI intake was the highest when rations containing concentrate with keratin meal and maize were fed, and the lowest when the combination lupin with barley was provided. Intake of UFL was higher $(\mathrm{P}<0.01)$ when rations contained lupin and maize than when other combinations of protein and starch were fed. The mean value of the (PDIE-PDIN)/UFL ratio was $-7.4 \mathrm{~g}$ for groups fed lupin and $-3.4 \mathrm{~g}$ for groups fed keratin meals.

The total and daily milk yields for the experimental period (Table 4, Figure 1) were higher $(\mathrm{P}<0.05)$ when lupin, not keratin, was the main source of protein and when cows received not only starch but also rape seeds as energy sources $(\mathrm{P}<0.05)$. The source of starch, barley or maize, in the diet did not differentiate milk yield $(\mathrm{P}>0.05)$. Total production of protein and lactose in milk of cows fed lupin as the protein source was higher $(\mathrm{P}<0.01)$ with a slight tendency for fat to increase in comparison with keratin as the main source of protein in the diet. Rape seeds fat compared with starch as the main source of energy in the diet favoured a higher production of lactose $(\mathrm{P}<0.01)$ with a tendency towards increased fat production in milk.

Concentration of dry matter, fat, protein and lactose in milk did not depend on the protein, starch or energy source in the diet $(\mathrm{P}<0.05)$ although a slight tendency for fat to increase and protein to decrease was found when lupin was 
TABLE 2

Chemical composition of feeds (\%), fermentation products ( $\mathrm{FP}=$ lactic acid + volatile fatty acids) and nutritive value of $1 \mathrm{~kg}$ DM of feeds according to IZ-INRA system

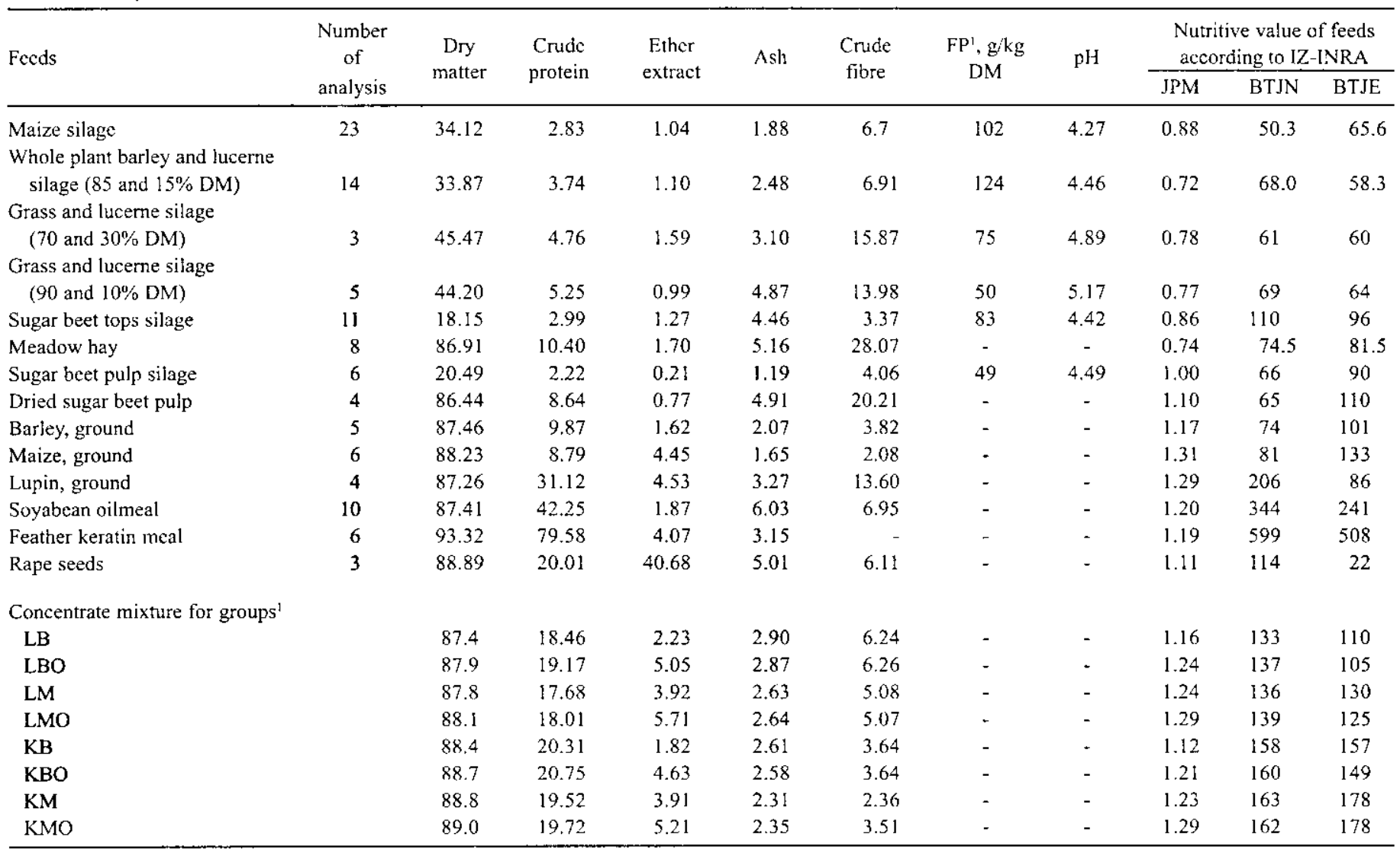

1 as in Table 1 
Average daily nutrients intake

TABLE 3

Average daily nutrients intake

\begin{tabular}{|c|c|c|c|c|c|c|c|c|}
\hline \multirow{2}{*}{ Item } & \multicolumn{2}{|c|}{ Protein source } & \multicolumn{2}{|c|}{ Starch source } & \multicolumn{2}{|c|}{ Energy source } & \multirow{2}{*}{$\mathrm{RMSE}^{1}$} & \multirow{2}{*}{$\begin{array}{c}\text { Interaction } \\
\text { protein } \mathrm{x} \text { starch }{ }^{2}\end{array}$} \\
\hline & lupin & keratin & barley & maize & starch & starch + oil & & \\
\hline Dry matter, kg & 23.9 & 23.7 & 23.5 & 24.0 & 23.8 & 23.7 & 2.67 & $\mathrm{~ns}^{3}$ \\
\hline Crude protein, $g$ & 3673 & 3694 & 3692 & 3673 & 3652 & 3714 & 352.1 & ns \\
\hline PDIN, g & $2364^{A}$ & $2515^{\mathrm{B}}$ & 2423 & 2456 & 2381 & 2497 & 227.7 & $x x$ \\
\hline PDIE, $g$ & $2195^{A}$ & $2439^{B}$ & $2228^{a}$ & $2406^{b}$ & 2314 & 2320 & 217.8 & $x x$ \\
\hline $\mathrm{UFL}$ & 23.1 & 22.6 & 22.5 & 23.1 & 22.6 & 23.0 & 1.89 & $\mathrm{xx}$ \\
\hline
\end{tabular}

Significance of differences beetwen groups to interaction: protein $\mathrm{x}$ starch

\begin{tabular}{ccc}
\hline Groups $^{4}$ & \multicolumn{2}{c}{ Average values } \\
\hline & PDI & UFL \\
LB & $2098^{\wedge}$ & $22.2^{\wedge}$ \\
LM & $2294^{\mathrm{B}}$ & $23.3^{\mathrm{B}}$ \\
$\mathrm{KB}$ & $2329^{\mathrm{B}}$ & $22.4^{\mathrm{A}}$ \\
$\mathrm{KM}$ & $2534^{\mathrm{C}}$ & $22.6^{\mathrm{A}}$ \\
\hline
\end{tabular}

\footnotetext{
$1 \sqrt{s^{2}}$
}

2 remaining interactions were not significant statistically

3 not significant

4 as in Table

${ }^{\text {ab }} \mathrm{P} \leq 0.05 ;{ }^{\mathrm{ABC}} \mathrm{P} \leq 0.01 ; \mathrm{xx}-\mathrm{P} \leq 0.01$ 
TABLE 4

Total and daily milk production and composition and fat and protein production

\begin{tabular}{|c|c|c|c|c|c|c|c|c|}
\hline \multirow{2}{*}{ Item } & \multicolumn{2}{|c|}{ Protein source } & \multicolumn{2}{|c|}{ Starch source } & \multicolumn{2}{|c|}{ Energy source } & \multirow{2}{*}{ RMSE' } & \multirow{2}{*}{$\begin{array}{c}\text { Interaction } \\
\text { protein } \mathrm{x} \text { starch }\end{array}$} \\
\hline & lupin & keratin & barley & maize & starch & starch + oil & & \\
\hline Daily milk production, $\mathrm{kg}$ & $34.7^{\mathrm{a}}$ & $32.8^{b}$ & 33.4 & 34.07 & $33.02^{\mathrm{a}}$ & $34.49^{b}$ & 4.49 & ns \\
\hline Milk fat, $\%$ & 4.03 & 4.08 & 4.07 & 4.08 & 4.06 & 4.09 & 0.29 & ns \\
\hline Milk protein, $\%$ & 3.17 & 3.13 & 3.16 & 3.15 & 3.17 & 3.13 & 0.18 & $\mathrm{x}$ \\
\hline Milk lactose, $\%$ & 4.83 & 4.85 & 4.82 & 4.85 & 4.84 & 4.86 & 0.18 & ns \\
\hline Lactose production, $\mathrm{kg}$ & $167.6^{\mathrm{A}}$ & $159.1^{\mathrm{B}}$ & 161.2 & 165.3 & $159.8^{\mathrm{A}}$ & $167.6^{\mathrm{B}}$ & 22.64 & ns \\
\hline
\end{tabular}

Significant differences beetwen groups for interaction protein $\mathrm{x}$ starch

\begin{tabular}{cc}
\hline Groups $^{3}$ & Values for milk protein \\
\hline LB & $3.22^{\mathrm{a}}$ \\
LM & $3.14^{\mathrm{b}}$ \\
KB & $3.14^{\mathrm{b}}$ \\
KM & $3.15^{\mathrm{b}}$ \\
\hline
\end{tabular}

$1 \sqrt{s^{2}}$

2 remaining interactions were not significant statistically

3 as in Table 1

ab $\mathrm{P}<0.05 ;{ }^{\mathrm{AB}} \mathrm{P}<0.01 ; \mathrm{x}-\mathrm{P}<0.05 ; \mathrm{ns}$ - interaction statistically no significant 


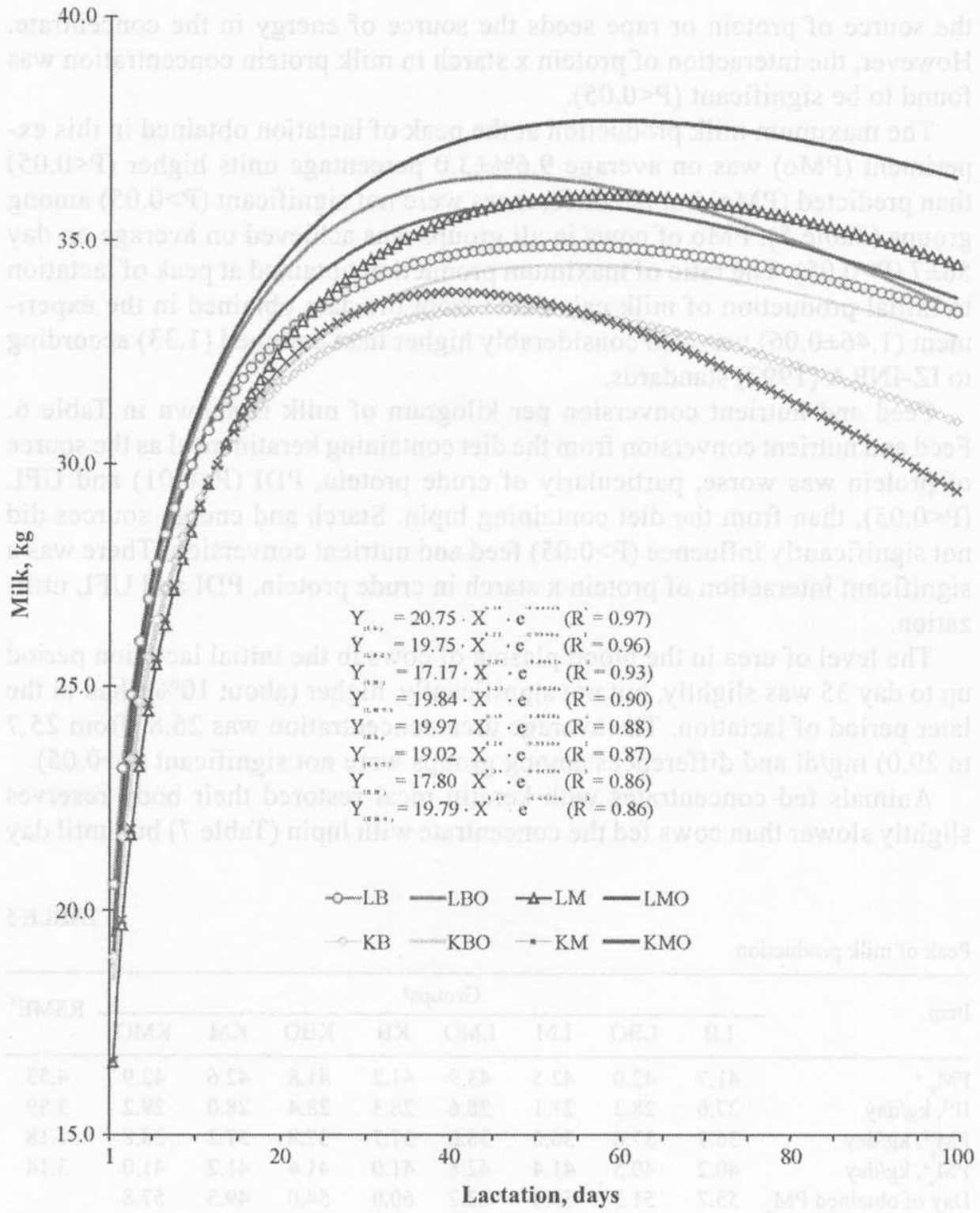

Figure 1. Lactation patern 
the source of protein or rape seeds the source of energy in the concentrate. However, the interaction of protein $\mathrm{x}$ starch in milk protein concentration was found to be significant $(\mathrm{P}<0.05)$.

The maximum milk production at the peak of lactation obtained in this experiment $(\mathrm{PMo})$ was on average $9.6 \% \pm 3.0$ percentage units higher $(\mathrm{P}<0.05)$ than predicted $(\mathrm{PMp})$ but the differences were not significant $(\mathrm{P}>0.05)$ among groups (Table 5). PMo of cows in all groups was achieved on average on day $56 \pm 7(\mathrm{P}>0.05)$. The ratio of maximum production obtained at peak of lactation to initial production of milk calculated from the data obtained in the experiment (1.46 \pm 0.06$)$ was also considerably higher than assumed (1.33) according to IZ-INRA (1997) standards.

Feed and nutrient conversion per kilogram of milk is shown in Table 6. Feed and nutrient conversion from the diet containing keratin meal as the source of protein was worse, particularly of crude protein, PDI $(\mathrm{P}<0.01)$ and UFL $(\mathrm{P}<0.05)$, than from the diet containing lupin. Starch and energy sources did not significantly influence $(\mathrm{P}>0.05)$ feed and nutrient conversion. There was a significant interaction of protein $\mathrm{x}$ starch in crude protein, PDI and UFL utilization.

The level of urea in the blood plasma of cows in the initial lactation period up to day 35 was slightly, but not significantly, higher (about 10\%) than in the later period of lactation. The average urea concentration was 26.8 (from 25.7 to 29.0$) \mathrm{mg} / \mathrm{dl}$ and differences among groups were not significant $(\mathrm{P}>0.05)$.

Animals fed concentrates with keratin meal restored their body reserves slightly slower than cows fed the concentrate with lupin (Table 7) but until day

TABLE 5

Peak of milk production

\begin{tabular}{|c|c|c|c|c|c|c|c|c|c|}
\hline \multirow{2}{*}{ Item } & \multicolumn{8}{|c|}{ Groups ${ }^{\prime \prime}$} & \multirow{2}{*}{$\mathrm{RSME}^{5}$} \\
\hline & LB & LBO & $\mathrm{LM}$ & LMO & $\mathrm{KB}$ & $\mathrm{KBO}$ & KM & $\mathrm{KMO}$ & \\
\hline $\mathrm{PM}_{\| 1}{ }^{1}$ & 41.7 & 42.0 & 42.5 & 43.9 & 41.2 & 41.8 & 42.6 & 42.9 & 4.53 \\
\hline $\mathrm{IP}^{2}, \mathrm{~kg} /$ day & 27.6 & 28.3 & 27.1 & 28.6 & 28.3 & 28.4 & 28.0 & 29.2 & 3.89 \\
\hline $\mathrm{PM}_{\mathrm{p}}^{3}, \mathrm{~kg} / \mathrm{day}$ & 36.7 & 37.6 & 36.0 & 38.0 & 37.7 & 37.8 & 37.2 & 38.8 & 5.18 \\
\hline $\mathrm{PM}^{\mathrm{p}}{ }^{4}, \mathrm{~kg} /$ day & 40.2 & 40.5 & 41.4 & 42.8 & 41.0 & 41.4 & 41.2 & 41.0 & 3.14 \\
\hline Day of obtained PM. & 55.7 & 51.3 & 59.4 & 62.2 & 60.0 & 54.0 & 49.5 & 57.8 & \\
\hline
\end{tabular}

$1 \mathrm{PM}_{11}$ - production maximum of last lactation calculated as quotient: 300 day lactation output $/ 190$ (IZ-INRA, 1997)

${ }^{2}$ IP - initial production (the mean daily production on the 4th, 5th and 6th day of lactation)

3. $\mathrm{PM}_{\mathrm{p}}$ - production maximum predicted $=$ IP $\times 1,33$ (IZ-INRA, 1997)

$4 \mathrm{PM}_{\mathrm{o}}^{\mathrm{P}}$ - production maximum obtained

$5{\sqrt{\mathrm{s}^{2}}}^{0}$

${ }^{6}$ as in Table 1 
TABLE 6

Concentrate feed and nutrients conversion per $1 \mathrm{~kg}$ milk

\begin{tabular}{|c|c|c|c|c|c|c|c|c|}
\hline \multirow{2}{*}{ Item } & \multicolumn{2}{|c|}{ Protein source } & \multicolumn{2}{|c|}{ Starch source } & \multicolumn{2}{|c|}{ Energy source } & \multirow{2}{*}{ RMSE $^{\prime}$} & \multirow{2}{*}{$\begin{array}{c}\text { Interaction } \\
\text { protein } x \text { starch }\end{array}$} \\
\hline & lupin & keratin & barley & maize & starch & starch + oil & & \\
\hline Concentrate, $\mathrm{kg}$ & 0.28 & 0.29 & 0.29 & 0.28 & 0.29 & 0.28 & 0.04 & $\mathrm{~ns}$ \\
\hline Crude protein, $\mathrm{g}$ & $104.7^{\mathrm{A}}$ & $112.6^{8}$ & 110.5 & 107.8 & 110.6 & 107.6 & 18.99 & $x x$ \\
\hline PDl, g & $63.2^{\mathrm{A}}$ & $74.4^{\mathrm{B}}$ & 66.7 & 70.6 & 70.1 & 67.3 & 12.14 & $\mathrm{x}$ \\
\hline UFL & $0.66^{\mathrm{a}}$ & $0.69^{b}$ & 0.67 & 0.68 & 0.68 & 0.67 & 0.11 & $\mathrm{x}$ \\
\hline
\end{tabular}

Significant differences beetwen groups for interaction protein $\mathrm{x}$ starch

\begin{tabular}{lccc} 
Groups $^{2}$ & \multicolumn{3}{c}{ Average values } \\
\cline { 2 - 4 } & crude protein & PDI & UFL \\
\hline LB & $107.2^{\mathrm{A}}$ & $61.9^{\mathrm{A}}$ & $0.65^{\mathrm{a}}$ \\
LM & $107.1^{\mathrm{A}}$ & $67.4^{\mathrm{A}}$ & $0.68^{\mathrm{ab}}$ \\
$\mathrm{KB}$ & $114.0^{\mathrm{B}}$ & $72.8^{\mathrm{B}}$ & $0.70^{\mathrm{b}}$ \\
$\mathrm{KM}$ & $114.9^{\mathrm{B}}$ & $78.9^{\mathrm{B}}$ & $0.70^{\mathrm{b}}$ \\
\hline
\end{tabular}

$1 \sqrt{s^{2}}$

2 as in Table 1

${ }^{\text {ab }} \mathrm{P}<0.05 ;{ }^{A B} \mathrm{P}<0.01 ; \mathrm{x}-\mathrm{P}<0.05 ; \mathrm{xx}-\mathrm{P}<0.01$; ns - not significant 
Changes in body weight of cows during experimental period

\begin{tabular}{|c|c|c|c|c|c|c|c|c|c|}
\hline \multirow{2}{*}{ Item } & \multicolumn{8}{|c|}{ Groups 2} & \multirow{2}{*}{$\mathrm{RSMF}^{\prime}$} \\
\hline & LB & LBO & $\mathrm{LM}$ & LMO & $\mathrm{KB}$ & $\mathrm{KBO}$ & $\mathrm{KM}$ & $\mathrm{KMO}$ & \\
\hline $\begin{array}{l}\text { Body weight before } \\
\text { calving, } \mathrm{kg}\end{array}$ & 732.5 & 755.8 & 738.2 & 723.0 & 743.4 & 723.7 & 748.3 & 722.1 & 68.78 \\
\hline \multicolumn{10}{|c|}{ Body weight after calving ( $\mathrm{kg}$ ), at the day } \\
\hline 2 & 649.9 & 677.6 & 659.9 & 640.6 & 667.8 & 650.5 & 686.8 & 657.4 & 63.66 \\
\hline 10 & 640.0 & 662.6 & 641.9 & 623.4 & 651.6 & 620.4 & 663.4 & 638.3 & 65.88 \\
\hline 35 & 632.9 & 652.6 & 640.1 & 614.0 & 639.3 & 618.5 & 651.6 & 63.8 & 62.09 \\
\hline 84 & $639.4^{\text {at }}$ & $670.8^{a}$ & $642.5^{\mathrm{ab}}$ & $629.1^{\mathrm{sb}}$ & $633.2^{\mathrm{ab}}$ & $616.0^{\mathrm{h}}$ & $653.9^{\text {th }}$ & $627.3^{\mathrm{b}}$ & 57.96 \\
\hline 100 & $642.8^{\mathrm{sb}}$ & $673.7^{\circ}$ & $649.1^{\text {at }}$ & $634.3^{\mathrm{ab}}$ & $626.0^{\mathrm{b}}$ & $618.5^{\mathrm{b}}$ & $658.0^{\mathrm{ab}}$ & $627.8^{b}$ & 58.77 \\
\hline $\begin{array}{l}\text { Ratio of body weight a } \\
\text { the day } 100 \text { to body } \\
\text { weight at the day } 2 \\
\text { after calving, } \%\end{array}$ & 98.9 & 99.0 & 98.4 & 99.0 & 93.7 & 95.1 & 95.8 & 95.4 & 5.01 \\
\hline
\end{tabular}

84 of the experiment, differences between the groups of animals in body weight were not significant.

The total content of saturated and unsaturated fatty acids in milk fat (Table 8) did not differ significantly among groups. However, in the milk fat of cows fed keratin meal instead of lupin, inconsiderably lower concentrations of $\mathrm{C}_{4}$ to $\mathrm{C}_{12}$ fatty acids were observed, and indeed, a decrease of miristic $\left(\mathrm{C}_{140}\right)(\mathrm{P}<0.05)$, palmitic $\left(\mathrm{C}_{16: 1)}\right)(\mathrm{P}<0.05)$, miristoleic $\left(\mathrm{C}_{14: 1}\right)(\mathrm{P}<0.01)$, stearic $\left(\mathrm{C}_{18: 0}\right)(\mathrm{P}<0.01)$, oleic $\left(\mathrm{C}_{18: 1}\right)(\mathrm{P}<0.05)$, and linolenic $\left(\mathrm{C}_{18: 3 \mathrm{n}-3}\right)(\mathrm{P}<0.05)$ acids was seen, and there was a tendency toward increased concentrations of palmitoleic acid $\left(\mathrm{C}_{16: 1}\right)$ and decreased concentration of linoleic acid $\left(\mathrm{C}_{18: 2 \mathrm{n}-6}\right)$.

In milk from cows fed maize meal, the content of palmitic acid $\left(\mathrm{C}_{18: 0}\right)$ was higher $(\mathrm{P}<0.05)$ than from cows fed barley meal, but the content of saturated fatty acids was lower $(\mathrm{P}<0.05)$ and there was a slight decrease of unsaturated fatty acids with a significant difference $(\mathrm{P}<0.01)$ only for palmitoleic acid $\left(\mathrm{C}_{16: 1}\right)$.

Cows receiving rape seeds as a component of concentrate compared with cows fed starch significantly decreased the proportion of palmitic $\left(\mathrm{C}_{16: 0}\right)$, margaric $\left(\mathrm{C}_{17: 0}\right)$, palmitoleic $\left(\mathrm{C}_{16: 1}\right)$ and heptadecanoic $\left(\mathrm{C}_{17: 1}\right)$ acids but significantly increased the concentration of linoleic acid $\left(\mathrm{C}_{18: 2 \mathrm{n}-6}\right)$ and conjugated linoleic acids (CLA) with tendency towards increasing oleic $\mathrm{C}_{18: 1}$ and linolenic acids $\left(\mathrm{C}_{18: 3 n-3}\right)$. 
TABLE 8

Fatty acids - saturated (SFA) and unsaturated (UFA) contents in milk fat, $\%$

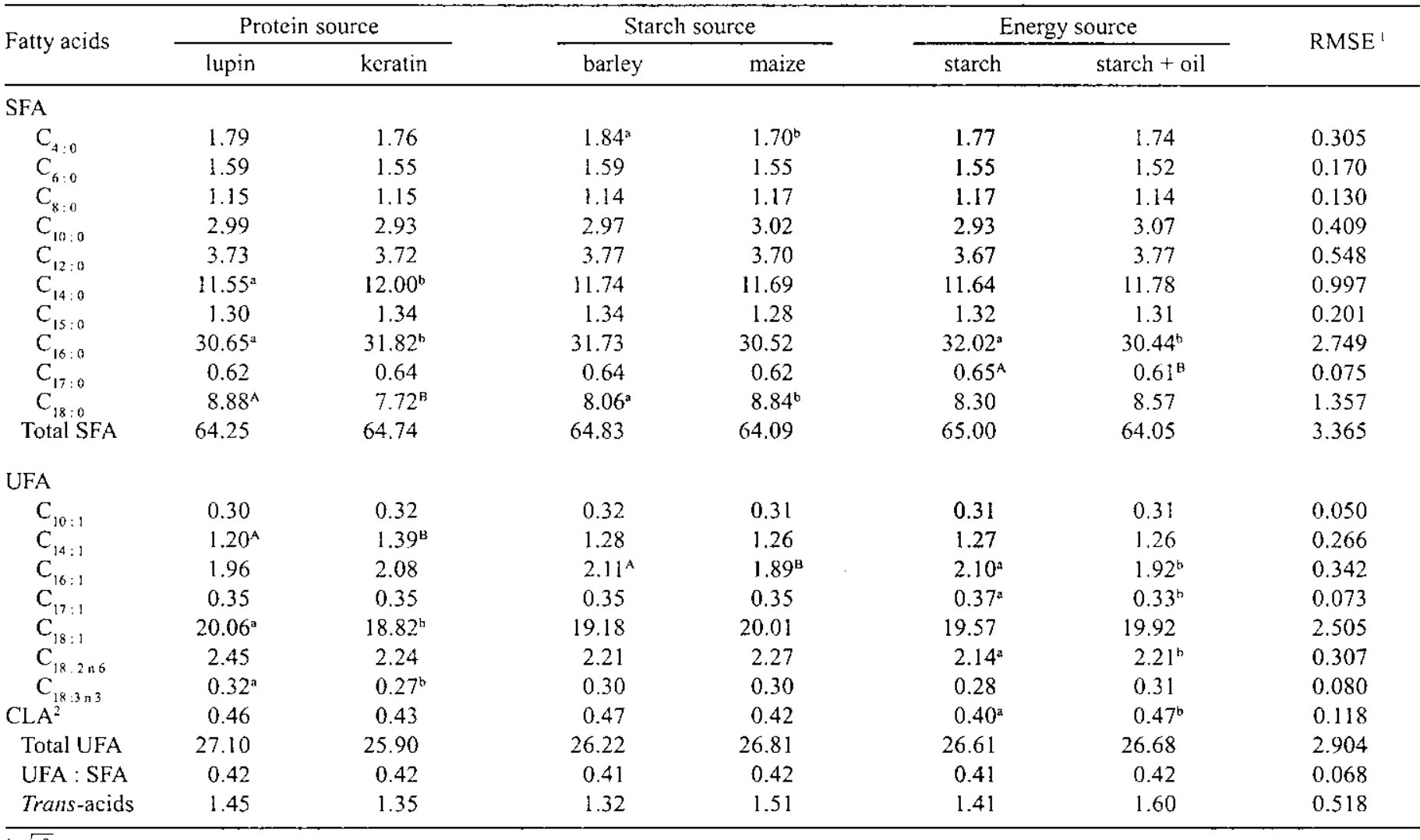

${ }^{a b} \mathrm{P} \leq 0.05 ;{ }^{\mathrm{AB}} \mathrm{P} \leq .01 ; \mathrm{x}-\mathrm{P} \leq 0.05 ; \mathrm{xx}-\mathrm{P} \leq 0.01$ 


\section{DISCUSSION}

It is possible to influence the pattern of digestibility processes occurring in the rumen and intestine by selection of feeds according to their physico-chemical properties and amount in the diet. This in turn determines the proportion of precursors of milk components absorbed into the blood, milk yield and composition (Wu and Huber, 1994; Schingocthe, 1996; Santos et al., 1998; Castillo et al., 2000).

In the current experiment, independent of dict composition, daily dry matter intake was about $3.7 \%$ of the body weight of cows producing daily on average $34.8 \mathrm{~kg}$ of milk. This corresponds with the results of experiments by Khorasani et al. (1994) on cows fed rations with different sources of protein and starch showing dry matter intake about $3.9 \%$ of body weight and producing $30 \mathrm{~kg}$ of milk daily. Nombekela and Murphy (1995) or Chalupa and Snifen (1996) reported a similar dry matter intake of about $4 \%$ of body weight by high yielding cows, while the dry matter intake of cows producing less milk was usually about $2 \%$ of body weight. The relatively high milk production in our experiment, low proportion of (PDIE - PDIN)/UFL and low concentration of urea in milk suggest an appropriate protein and energy balance in the ration formulated according to IZ-INRA (1997) recommendations. The significant interaction of PDI $x$ UFL on nutrient intake resulted from the different sources of protein and energy in the concentrate being balanced in the rations used. The lower milk yicld in cows fed rations with slowly degradable keratin meal protein might be caused by limited microbial protein synthesis in the rumen and, as a consequence, lower amino acid delivery to the small intestine. Santos et al. (1998) summarizing the results of numerous experiments carried out in 1985-1997 showed that an increased proportion of undegradable protein in the diet may decrease microbial protein synthesis in the rumen, exert an influence on the profile of amino acids absorbed from the intestine, but did not always increase milk yield. The level of crude protein in diets with keratin meal and lupin was similar, about $15.5 \%$ of dry matter. Inclusion of about $20 \%$ of keratin meal into the diet increased the amount of intestinally digested protein (PDI) containing about $18 \%$ of intestinally digested protein of feed origin and it can be presumed that in this case the deficit of rumen degradable protein could be a limiting factor of milk production in contrast with the group of cows producing more milk when receiving easily degradable lupin protein that stimulates microbial synthesis (Table 4, Figure 1). Such an explanation may be supported by the finding that the deficit of energy available for rumen microorganisms or degradable protein in the diet can decrease milk production (Waltz et al., 1989; DePeters and Cant, 1992; Schingoethe, 1996). It is possible that the site of starch digestion, resulting from its physico-chemical properties (Mills et al., 1999) is of secondary importance to the energy balance of high-producing cows (Poor et al., 1993). 
Different sources of barley or maize starch in the diet for cows did not affect milk production (Table 4). A similar result was obtained by Grings et al. (1992) in an experiment on cows fed diets with similar sources of starch as in our experiment. The similar rate of lactation (Figure l) in groups LB and LM or KB and KM and lack of significant differences in milk production of cows fed diets with barley or maize starch show also that the source of starch had no significant influence on lactose synthesis, which is a factor limiting milk production.

The significantly higher (about 5\%) milk and lactose production (Table 4, Figure 1) in cows receiving diets with rape seeds than in cows fed dietscan without them is consistent with the opinion that cows on fat-supplemented diets can produce more milk (Shingoethe and Casper, 1991; DePeters and Cant, 1992; Chan et al., 1997).

The increased level of fat (from 2.84 to $3.67 \%$ of dry matter) in the diets supplemented with rape seeds did not increase the fat level or decrease the protein level in milk significantly, indicating that supplemented fat had only a slight influence on processes occurring in the rumen and on nutrient digestibility. The effect of adding fat to the diet is variable depending on the level and source of this component. Opinions concerning the metabolic patterns leading to decreases of the protein content in the milk of cows fed diets with elevated fat contents are inconsistent, but all authors are concordant that excessive fat in the diet generates a reduction of the amino acid supply to the mammary gland (Grummer, 1991; Palmquist et al., 1993; Wu and Huber, 1994; Doreau and Chilliard, 1997).

In milk from cows fed diets with lupin as a source of protein, a tendency towards a higher, although not significant, protein and lower fat content was observed compared with milk from cows fed keratin meal. This could probably be caused by a higher ratio of propionic to acetic acid in the rumen of cows fed lupin (Waltz et al., 1989; Erazmus and Botha, 1994). A higher content of protein in milk produced by cows receiving diets with lupin combined with starch gave a significant protein $\mathrm{x}$ starch interaction on protein concentration in milk, indicating that synchronism of protein and carbohydrate fermentation in the rumen might be an important factor influencing the protein content in milk. The worse efficiency of protein and energy in feeding rations with keratin meal compared with lupin also indicates that the protein source influenced milk production, although protein's influence also depended on the source of starch in the diet.

The maximum milk production obtained (PMo) in this experiment was about $10 \%$ higher than the predicted maximum production $(\mathrm{PMp}=\mathrm{IP} \times 1.33)$, thereby a higher ratio of maximum production obtained to predicted production (1.46) than the value (1.33) given by INRA (1988). This suggests that values for protein and energy requirements in the initial lactation period are underestimated and do not correspond to actual requirements of cows for these nutrients. The reason for this discrepancy could also be that initial production (IP) might have been too low as it 
may be dependent, among others, on the level of feeding in the period from the third week before calving to the first week after calving, as found on the basis of maximum production obtained during the last lactation $\left(\mathrm{PM}_{11}\right)$ (Strzetelski, 1997). The feeding level set for this period did not account for the cow's energy requirement for lactogenesis and development of the uterus (Bell et al., 1995; Olson et al., 1998; Vandehaar et al., 1999), possibly having a negative effect on initial production. This index may be also elusory as the sequence of lactation also influences milk yield (Hibner, 1991; Strzetelski et al., 1997; Olson et al., 1998).

Higher losses of body weight from day 2 to 100 of lactation as well as lower milk yield and feed efficiency in cows fed the diet with keratin meal $(-329 \mathrm{~g} /$ day $)$ than those fed lupin $(-70.2 \mathrm{~g} /$ day $)$ indicate better coverage of nutrient requirements by lupin than keratin meal. Similar body weight changes of cows fed diets with poorly and highly rumen undegraded protein from day 5 to 75 of lactation were reported by Wu et al. (1997).

The slightly higher plasma concentrations of urea in cows in the initial period of lactation resulted from the higher protein content in the diets in this period than in the further period of the experiment.

The slightly lower concentration of $\mathrm{C}_{4: 0}$ to $\mathrm{C}_{12: 0}$ fatty acids in the milk of cows fed the diet with keratin meal than lupin could be probably explained by the expected lower microbial synthesis and limited production of these acids in the rumen of cows of this group. Thomlinson et al. (1994) also showed the negative effect of keratin or blood meal protein undegradable in the rumen in the diet on the concentration of fatty acids in the rumen.

The somewhat lower concentration of most of saturated fatty acids in the milk of cows fed barley starch than starch of maize origin could also result from increased de novo synthesis in the rumen of fatty acids because of easier fermentation of barley starch than that of maize origin. Khorosani et al. (1994) showed that substitution of barley starch by maize starch in the diet decreases de novo synthesis of fatty acids and their content in milk. It seems that a higher content of $\mathrm{C}_{18: 0}$ and $\mathrm{C}_{18: 1}$ acids in milk fat from cows fed lupin and maize originated from biohydrogenation in the rumen of $\mathrm{C}_{18: 2}$ acid, the content of which is some $50 \%$ higher in these feeds than in keratin meal or barley (Palmquist and Schaubacher, 1991; NISO, 1994). The higher content of $C_{18: 1}$ acid in the milk fat of cows fed diets with lupin than keratin meal and the greater tendency to increase this acid in the milk of cows fed maize than barley suggests that more of this acid avoided biohydrogenation in the rumen. The tendency to increase the $\mathrm{C}_{18: 0}$ acid in milk by feeding rations with rape seeds likely resulted from high intake, about $200 \mathrm{~g} /$ day of rape seeds that contained $51.2 \%$ of $\mathrm{C}_{18: 1}$ and $20.5 \%$ of $\mathrm{C}_{18: 2 \text { n- } 6}$ acids (Strzetelski et al., 1998). The reason for the increased concentration of $\mathrm{C}_{18: 1}$ acid in the milk of cows fed the diet with rape seeds compared with starch as source of energy could be the elongation of $\mathrm{C}_{16: 0}$ suggested by the lower content of this acid in the milk of cows fed 
the diet with rape seeds. The significantly higher content of $\mathrm{C}_{18: 2}$ conjugated linoleic acids in the milk of cows fed rape seeds was a consequence of the higher intake of $\mathrm{C}_{18: 2 \mathrm{n}-\mathrm{6}(\mathrm{d}}(42 \mathrm{~g} / \mathrm{day})$ and limited biohydrogenation (Murphy ct al., 1990) of $\mathrm{C}_{18: 2}$ conjugated linoleic acids synthesised in the rumen (Parodi, 1999). The content of trans-acids in milk in our experiment was lower than in the experiment of Kenclly et al. (1999) who fed cows rations with a dry matter ratio of concentrate to roughage of 50:50 whereas this ratio in our experiment was 40:60.

\section{CONCLUSIONS}

Differences in feed protein degradation in the rumen can affect milk yield and milk component efficiency in highly productive cows despite protein and energy being balanced according to IZ-INRA (1997) standards. The source of starch in the diet has a rather limited effect on these indices. A significant interaction of protein $\mathrm{x}$ starch on protein content in milk confirms the suggestion that synchronism of protein and energy needed for microbial synthesis in the rumen can influence the level of protein in milk. Feeding diets supplemented with rape seed fat (up to $200 \mathrm{~g}$ of rape seeds per day) advantageously affects milk yield without decreasing the protein level in the milk. Changes in the dietary source of protein as well as of starch and rape seeds as sources of energy results in only small changes in the proportions of individual fatty acids in milk fat. The effect of rape seed oil on milk production does not depend on the components of the diet as the interaction protein $\mathrm{x}$ starch $\mathrm{x}$ vegetable oil was not significant.

\section{REFERENCES}

AOAC, 1990. Association of Official Analytical Chemists. Official Methods of Analysis. 15th Edition. Arlington, VA

Beever D.E., 1993. Rumen function. In: J.M. Forbes, J. France (Editors). Quantitative Aspects of Ruminant Digestion and Metabolism. CAB lnternational, Wallingford (UK), pp.187-215

Bell A.W., Slepetis R., Erhardı R.A., 1995. Growth and secretion of energy and protein in the gravid utcrus during late pregnancy in Holstein cows. J. Dairy Sci. 78, 1954-1961

Castillo A.R., Kebreab E., Beever D.E., France J., 2000. A review of efficiency of nitrogen utilisa* tion in lactating dairy cows and its relationship with environmental pollution. J. Anim. Feed Sci. $9,1-32$

Chalupa W., Sniffen C.J., 1996. Protein and amino acid nutrition of lactating dairy cattle - today and tomorrow. Anim. Feed Sci. Tech. 58, 65-75

Chan S.C., Huber J.T., Theurer C.B., Wu Z., Chen K.H., Simas J.M., 1997. Effects of supplemental fat and protein source on ruminal fermentation and nutrient flow to the duodenum in dairy cows.

J. Dairy Sci. $80,152-159$ 
DePeters E.J., Cant J.P., 1992. Nutritional factors influencing the nitrogen composition of bovine milk: A Review. J. Dairy Sci. 75, 2043-2070

Dijkstra J., France J., Davies D.R., 1998. Different matenatical approaches to estimating microbial protein supply in ruminants. J. Dairy Sci. 81, 3370-3384

Doreau M., Chilliard Y., 1997. Digestion and metabolism of dietary fat in farm animals. Brit. J. Nutr. 78, Suppl. 1, S15-S35

Erasmus L.J., Botha P.M., 1994. Effect of protein source on ruminal fermentation and passage of amino acids to the small intestine of lactating cows. J. Dairy Sci. 77, 3655-3665

Grings E.E., Roffler R.E., Deitelhoff D.P., 1992. Evaluation of corn and barley as energy sources for cows in early lactation fed alfalfa-based diets. J. Dairy Sci. 75, 193-200

Grummer R.R., 1991. Effect of feed on the composition of milk fat. J. Dairy Sci. 74, 3244-3257

Henderson A.R., Garnsworthy P.C., Newbold J.R., Buttery P.J., 1998. The effect of asynchronous diets on the function of the rumen in the laclating dairy cows. Proc. Brit. Soc. Anim. Sci., p. 19 (Abstr.)

Hibner A., 1991. The efficiency of performance at production conditions of cows Black-and-White Lowland breeds with comparison to crossbreds with $50 \%$ and $25 \%$ gens of Holstein-Fresian breeds (in Polish). Zesz. Nauk. AR Wroc ${ }^{3}$ aw, Thesis, 94, 5-50

Hongerhold D.D., Muller L.D., 1998. Supplementation of rumen-undegradable protein to the diets of carly lactation Holstein cows on grass pasture. J. Dairy Sci. 81, 2204-2214

Hoover W.H., Stokes S.R., 1991. Balancing carbohydrates and proteins for optimum rumen microbial yield. J. Dairy Sci. 74, 3630-3644

INRA, 1988. Alimentation des Bovins, Ovins, Caprins. R, Jarrige (Editor). INRA. Paris, pp. 135184

IZ-INRA, 1997. Standards for Cattle, Sheep and Goat Nutrition (in Polish). Research Institute of Animal Production, Kraków (Poland)

Kennclly J.J., Robinson B., Khorasani G.R., 1999. Influence of carbohydrate source and buffer on rumen fermentation characteristics, milk yield and milk composition in early-lactation Holstein cows. J. Dairy Sci. 82, 2486-2496

Khorasani G.R., De Boer G., Robinson B., Kennelly J.J., 1994. Influence of dietary protein and starch on production and metabolic responses of dairy cows. J. Dairy Sci. 77, 813-824

Kolver E., Muller L.D., Varga G.A., Cassidy T.A., 1998. Synchronization of ruminal degradation of supplemental carbohydrates with pasture nitrogen in lactation dairy cows. J. Dairy Sci. 81, 2017. 2028

Mann J.M., 1964. Determination of fatty acids composition of milk fat by dual column temperature programmed gas - liquid chromatography. J. Dairy Sci. 47, 546-547

Mills J.A.N., France J., Dijkstra J., 1999. A review of starch digestion in the lactating dairy cow and proposals for a mechanistic model: 1 . Dietary starch characterisation and ruminal starch digestion. J. Anim. Feed Sci. 8, 291-340

Murphy J.J., McNell G.P., Connolly J.F.,, Glesson P.A., 1990. Effect on cow performance and milk fat composition of including full fat soya bean and rape seed in the concentrate mixture for lactating dairy cows. J. Dairy Res. 57, 295-306

NISO, 1994. Novis International Sales Offices. Row Material Compendium a Compilation of Worldwide Date Sources, NOVUS, pp. 3-5, 6-8, 261-262, 457

Nombekcla S.W., Murphy M.R., 1995. Sucrose supplementation and feed intake of dairy cows in early lactation. J. Dairy Sci. 78, 880-885

Olsson G., Emanuclson M., Wiktorsson H., 1998. Effects of different nutritional levels prepartum on the subsequent performance of dairy cows. Livest. Prod. Sci. 53, 79-290 
Palmquist D.L., Schanbacher F.L., 1991. Dictary fat composition influences fatty acid composition of milk fat globule membrane in lactating cows. Lipids 26, 718-738

Palmquist D.L., Beaulicu A.D., Barbano D.M., 1993. Feed and animal factors influencing milk fat composition. J. Dairy Sci. 76, 1753-1771

Parodi P.W., 1999. Conjugated linoleic acid and other anticarcinogenic agents of bovine milk fat. J. Dairy Sci. $82,1339-1349$

Poore M.H., Moore J.A., Eck T.P., Swingle R.S., Theurer C.B., 1993. Effect of fiber source and ruminal starch degradability on site and extent of digestion in dairy cows. J. Dairy Sci. 76, 22442253

Santos F.A.P., Santos J.E.P., Theurer C.B., Huber J.T., 1998. Effects of rumen-undegradable protein on dairy cow performance: A 12-year literature revicw. J. Dairy Sci. 81, 3182-3213

SAS, 1989. Users Guide, Statistics, Version 6, SAS, Inst. Inc. Cary, NC

Schingoethe D.J., 1996. Dietary influence on protein level in milk and milk yicld in dairy cows. Anim. Feed Sci. Tech. 60, 181-190

Schingocthe D.J., Casper D.P., 1991. Total lactational response to added fat during early lactation. J. Dairy Sci. 74, 2617-2622

Strzetelski J., 1997. Effect of rations balanced according to new principles on performance of homeland dairy cows of different genotype (in Polish). Rocz. Nauk. Zoot., Ann. Anim. Sci. Thesis, Research Institute of Animal P'roduction - Kraków. 5, 1-68

Strzetclski J.A., Kowalczyk J., Krawczyk K., Stasinicwicz T., Lipiarska E., 1998. Evening primrose (Oenothera paradoxa) oil cake or ground rape seed supplement to diets for dairy cows. J. Anim Fecd Sci. 7, 365-375

Strzetelski J.A., Kowalczyk J., Niwińska B., Bilik K., Maciaszek K., 1999. Nutritive value of feather keratin meals for ruminants. J. Anim. Feed Sci. 8, 387-393

Tomlinson A.P., Van Horn H.H., Wilcox C.J., Harris B. Jr., 1994. Effects of udegradable protein and supplemental fat on milk yield and composition and physiological responses of cows. J. Dairy Sci. $77,145-156$

Ulyatt M.J., 1997. Can protcin utilisation from pasture be improved? Proc. NZ Soc. Anim. Prod. 57, 4-8

Vandchaar M.J., Yousif G., Sharma B.K., Herdt T.H., Emery R.S., Allen M.S., Liesman J.S., 1999. Effect of energy and protein density of prepartum dicts on fat and protein metabolism od dairy cattle in the periparturient period. J. Dairy Sci. 82, 1282-1295

Waltz D.M., Stern M.D., IIlg D.J., 1989. Effect of numinal protein degradation of blood meal and feather meal on the intestinal amino acid supply to lactating cows. J. Dairy Sci. 72, 1509-1518

Wu Z., Huber J.T., 1994. Relationship between dietary fat supplementation and milk protein concentration in lactating cows. A review. L.ivest. Prod. Sci, 39, 141-155

Wu Z., Fisher R.J., Polan C.E., Schwab C.G., 1997. Lactational performance of cows fed low or high ruminally undegradable protein prepartum and supplemental methionine and lysine postpartum. J. Dairy Sci. $80,722-729$ 


\section{STRESZCZENIE}

\section{Wydajność i sklad mleka krów żywionych dawkami zawierającymi różne źródla energii i bialka}

Doświadczenie, w układzie trójczynnikowym, przeprowadzono na $15 \mathrm{I}$ krowach rasy cb, podziclonych na 8 grup metodą analogów, od wycielenia do setnego dnia laktacji. Badano wplyw rodzaju skarmianego bialka, trudno rozkładanego w żwaczu mączki keratynowej i łatwo rozkładanego nasion łubinu; rodzaju skarmianej skrobi, trudno fermentującej w żwaczu śruty kukurydzy i łatwo fermentującej jęczmienia; udziału tłuszczu zawartego w nasionach rzepaku ora z współdziałania tych czynników na wydajność mleczną krów i wykorzystanie paszy.

Dawki bilansowano wg norm IZ-INRA (1997). Krowy dojono dwa razy dziennie, kontrolując codziennie ilość udojonego mleka. Raz w tygodniu pobierano próbki mleka do oznaczenia zawartości tluszczu, bialka i laktozy. Dodatkowo, w próbach pobranych 35, 84 i 100 dnia laktacji, oznaczano zawartość mocznika, a w próbach z 100 dnia laktacji również zawartość kwasów tłuszczowych w thuszczu mleka. Krowy ważono w 21 dniu przed wycieleniem oraz w 2, 10, 35, 84 i 100 dni po wycieleniu.

Wykazano, żc mimo zbilansowania dawek pod względem zawartości energii i białka, rodzaj białka w dawce, różniącego się współczynnikiem rozkładu w żwaczu, może micć wpływ na wydajność mlcka i składników mleka krów wysokoprodukcyjnych. Stopień rozkładu skrobi w żwaczu nie miał istotnego wpływu na wielkość tych wskaźników. Najwyższa zawartość białka w mleku przy kombinacji łubin - jęczmień (istotna interakcja czynników białko x skrobia) wskazuje, że synchronizacja energii i białka dla potrzeb syntezy bakteryjnej może mieć wpływ na poziom białka w mleku. Zwiększone pobranie t!̣szczu, w postaci oleju zawartego w nasionach rzepaku, wplynęło dodatnio na wydajność mleka i laktozy, nie powodując istotnych zmian w procentowym składzie mleka. Wpływ nasion rzepaku na produkcyjność krów nie zależał od doboru pozostałych komponentów paszowych $\mathrm{z}$ uwzględnieniem stopnia rozkładu białka i wçglowodanów (nicistotna interakcja białko $\mathrm{x}$ skrobia $\mathrm{x}$ olej). Żród to biakka, skrobi i olej nasion rzepaku tylkow niewielkim stopniu powodowały zmiany w składzie kwasów tłuszczowych tłuszczu mleka. 